\title{
Genetic Structure Analysis of Leptin Gene/ Sau3ai and Its Relationship with Body Weghit in Iraqi and Holstein Frisian Cows Population (Comparative Study)
}

\author{
Dr. Da'ad Ali Hussain*, Zainab Hassan Abboud, Tabarek Amer Abdulameer* \\ Institute of Genetic Engineering and Biotechnology/University of Baghdad/Iraq
}

\begin{abstract}
Leptin (LEP), a peptide hormone secreted by adipose tissue cells, has been implicated in regulation of feed intake, energy balance, fertility, immune functions, and the neuroendocrine axis in rodents, humans and large domestic animals. This study aimed to evaluate the genetic polymorphism within LEP using PCR-RFLP technique as well as the association of these genotypes with body weight within local, cross, Holstein Frisian bovine as a comparison study. Genomic DNA extracted from 115 healthy bovine (60 local, 35 cross, 20 Holstein Frisian) and amplified using primers that were designed from the cattle LEP, and the structural gene polymorphism was applied using certain restriction enzyme (SAU3AI) throughout PCR-RFLP technique. There were two genotypes observed, the distribution of the two genotypes and allele frequency were calculated according to Hardy-Weinberg equation, $A A=40$ (48.78\%), 26 (31.715), 16 (19.51\%) and $A B=20$ (60.605\%), 9 (27.27\%), 4(12.12). LEP genotypes showed significant differences among local, cross and Holstein Frisian cows in all genotypes when comported with body weight $(B . W)$ and the P-value 0.0019 for AA genotype and 0.0027 for $A B$ genotype respectively $(P<0.01)$, with an increasing of $B . W$ in Holstein Frisian cows. However, the comparison within cross, local and HF themselves genotypes showed, no significant differences among these breeds and $P>0.05$.
\end{abstract}

Keywords: bovine, B.W, LEP, PCR-RFLP, SAU3AI.

\section{Introduction}

Leptin (LEP) is a hormone predominantly secreted from white adipose tissue and performs important roles in controlling body weight, milk production, feed intake, immune function and reproduction [1]. As the hormone LEP is involved in regulation of nutritional status and reproductive function, this hormone is an interesting protein to investigate during the periparturient period in dairy cattle [2]. The LEP gene is highly conserved across species, and is located on bovine chromosome 4q32. Its DNA sequence has more than 15,000 bp and contains three exons, which are separated by two intron. In fact LEP is encoded by a single transcript of $\sim 4.5$ bp expressed primarily by adipose tissue introns [3]. Several polymorphisms in the LEP gene were studies associated with milk performance $[4 ; 5 ; 6]$, increased perinatal mortality in dairy cattle [5], calf birth and weaning weights in beef and dairy cattle [7;8] and reproductive performance in dairy cattle [6] as well as better meat quality [8].

\section{Genomic DNA extraction}

\section{Materials And Methods}

The total numbers of blood samples were taken from vena jugulars of 115 from health cattle (60 local, 35 cross, 20 Holstein Frisian) with age ranged between 3-10 years and were accomplished by reserving them in EDTA tubes at $-20^{\circ} \mathrm{C}$. [6] Genomic DNA was extracted from whole blood samples with isolation kit, ReliaPrep ${ }^{\mathrm{TM}}$ Blood gDNA Miniprep System, (Promega, USA).

\section{Polymerase chain reaction $(\mathrm{PCR})$}

PCR technique was used to identify and amplify the target fragment band which includes Single Nucleotide Polymorphism (SNP) of LEPgene (422bp) by using specific primers according to Liefers et al., (2002) (Table 1). The PCR reaction was carried out in a 25ul reaction containing 12.5ul of Green Master Mix, $2 \mathrm{ul}$ of 10pmol/ul of LEP primer, 5ul of DNA template and the volume was completed to 25ul using nucleasefree water. The mixture was vortexes, we made sure all the liquid below the tube and then PCR tube was placed in PCR thermal cycler. 
Table 1: The Sequence of Primers that are used in the Procedures of this Study with Sizes of PCR Product and References.

\begin{tabular}{|r|c|c|r|r|}
\hline primer & \multicolumn{2}{|c|}{ Sequence } & Size & Reference \\
\hline \multirow{2}{*}{ LEP Gene } & F & $\mathbf{5}^{\prime}$-TGG AGT GGC TTG TTA TTT TCT TCT-3' & 422bp & Liefers et \\
\cline { 2 - 4 } & R & $\mathbf{5}^{\prime}$-GTC CCC GCT TCT GGC TAC CTA ACT- 3' & al. (2002) \\
\hline
\end{tabular}

PCR amplification was started according to the program described in table $2\{4\}$. Then, PCR products were separated on gel-electrophoresis. To confirm the presence of DNA and its band size, DNA bands were detected by UV Transilluminator and captured by a digital camera.

Table 2: PCR Amplification Program of LEP Gene.

\begin{tabular}{|c|c|c|c|}
\hline \multirow[t]{2}{*}{ Step } & \multicolumn{3}{|c|}{ LEPTIN-GENE } \\
\hline & Temp./C ${ }^{\circ}$ & Time/ Min. & Cycles \\
\hline Initial Denaturation & 95 & 4 & 1 \\
\hline Denaturation & 95 & 30 & \\
\hline Annealing & 62 & 30 & 35 \\
\hline Extension & 72 & 1 & \\
\hline Final Extension & 72 & 7 & 1 \\
\hline Hold & 4 & - & - \\
\hline
\end{tabular}

\section{Restriction Fragment Length Polymorphisms (RFLP) Technique}

PCR amplicons of LEP gene was digested by SAU3AI restriction enzyme. This procedure was accomplished by adding $10 \mu \mathrm{l}$ PCR product to $0.5 \mu \mathrm{l}$ (5 units) of certain restriction enzyme (SAU3AI) in sterile PCR tube $(0.2 \mathrm{ml})$ and adding $2 \mu 1$ of buffer attached with enzyme, then added $7.5 \mu 1$ nuclease free water. The total volume was $20 \mu 1$, PCR tubes placed in thermal cycler (Applied Biosystem, Singapore) and incubated for 3 hours in $37^{\circ} \mathrm{C}$, agarose gel electrophoresis technique were used to detect enzymatic digestion by loading all of the $20 \mu \mathrm{l}$ in the agarose gel well. DNA ladder (100bp) was used with $3 \%$ agarose gel stained with $1.5 \mu \mathrm{l}(10 \mathrm{mg}$ $/ \mathrm{ml}$ ) ethidium bromide, electrophoresed at 5 volt $/ \mathrm{cm}$ for 1.5 hour in $\mathrm{TBE}(1 \mathrm{X})$ buffer. After that it was visualized under UV Transillumenater and photographed by camera (Samsung, Korea).

\section{Result And Discussion}

PCR amplified region that located in a fragment extended between intron 2 to exon 3 on chromosome $4 q 32$ for LEP gene was improved by using specific primers described by (4). The best temperature for primer annealing (forward and reverse) with DNA template (annealing temperature) has been improved for appropriate time (optimization). After the PCR process was completed, the product electrophoresed on agarose gel (2\%) at 5 volt/cm for 1 hour, visualized under U.V light after staining with ethidium bromide by using the DNA ladder (100pb), all DNA samples were successfully amplified and they represented one band in an approximately size 422bp (Figure 1).

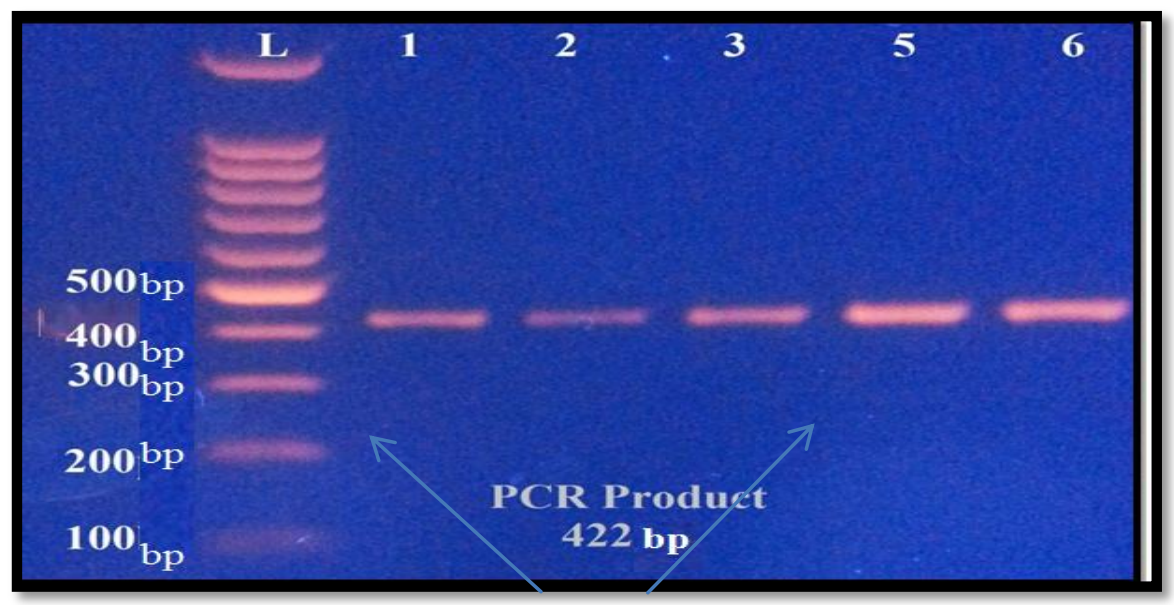

Figure 1: PCR Product of LEP gene. Band Size 422bp. Electrophoresis on $2 \%$ Agarose gel at 5volt/cm for 1hour, Visualized Under U.V Light After Staining with Ethidium Bromide. (L) 100bp DNA Ladder.

A single nucleotide polymorphism (SNP) inside the intron 2 of the bovine LEP gene based on the use of restriction fragment length polymorphism was detected. The digested AA PCR product exhibited two fragments of 390 and $32 \mathrm{bp}$, ( $32 \mathrm{bp}$ bands not detected on the gel) whereas the AB genotype gave three fragments 390, 303, 88 (Figure 2) 


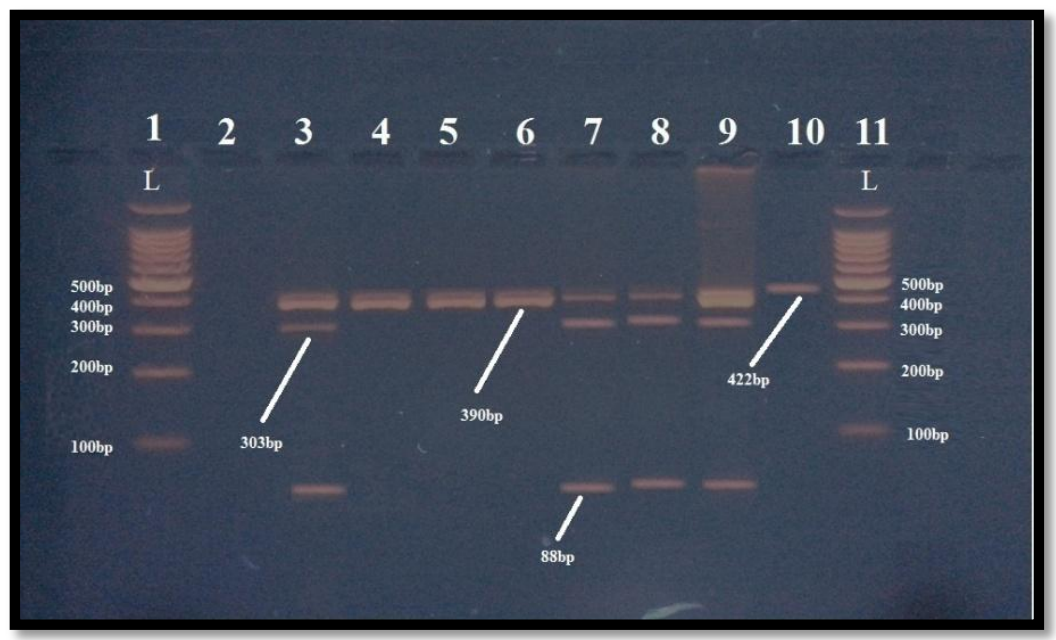

Figure 2: PCR-RFLP Analysis LEP Sau3AI loci on 3\% Agarose Gel.Lane 1,11 is Amarker of Molecular Weight (promega, 100 bp) lane 3,7,8,9 is AB Genotype (390,303 and 88 bp ,32), lane 4,5,6is AA Genotype (390 $\mathrm{bp}, 32 \mathrm{pb}$ ) and lane 10 is undigested PCRproduct (422 bp ).

The result revealed that, the higher frequency is found in A allele in all groups that involve in present study (local, cross and Holstein Frisian cows), with allelic values (0.83, 0.87, 0.90), respectively as compared with B allele values which were, $(0.17,0.13,0.10)$ in (local, cross and Holstein Frisian cows) (Table3).

Table 3: Allele Frequency of LEP Gene in Local, Cross breed and Holstein Frisian.

\begin{tabular}{|c|c|c|c|c|}
\hline \multirow{2}{*}{ Alleles } & \multicolumn{3}{|c|}{ Allele frequency of LEP Gene } & \multirow{2}{*}{$\begin{array}{c}\text { Cross } \\
\text { +Local } \\
\text { +Holstein Friesian }\end{array}$} \\
\cline { 2 - 4 } & Local & Cross & Holstein Friesian & $\mathbf{0 . 8 7}$ \\
\hline A & $\mathbf{0 . 8 3}$ & $\mathbf{0 . 8 7}$ & $\mathbf{0 . 9 0}$ & $\mathbf{0 . 1 3}$ \\
\hline B & $\mathbf{0 . 1 7}$ & $\mathbf{0 . 1 3}$ & $\mathbf{0 . 1 0}$ & $\mathbf{1 ( 1 0 0 \% )}$ \\
\hline Total & $\mathbf{1 ( 1 0 0 \% )}$ & $\mathbf{1 ( 1 0 0 \% )}$ & $\mathbf{1 ( 1 0 0 \% )}$ & \\
\hline
\end{tabular}

Similar observation suggested by [9] throughout their studies on Holstein-Friesian dairy cattle and [10] by their study on Holstein cows, they reported that the frequency of allele A was higher than allele B. There were two mainly genotypes of LEP gene identified which were: $\mathrm{AA}$ and $\mathrm{AB}$. When the comparison of these genotypes among local, cross and Holstein Friesian breeds was applied, there was significant result in AA genotype for local, cross and Holstein Frisian Breeds in this study and $\chi^{2}$-value was $9.516(\mathrm{P}<0.01)$. Another significant results in $\mathrm{AB}$ genotype between previous breed and the $\chi^{2}$-value was $12.847(\mathrm{P}<0.01)$. The distribution of LEP gene polymorphism in local, cross and Holstein Frisian bovines was estimated, using Chi-square test (Table 4).

Table 4: Distribution of LEP Gene Polymorphism in Local, Cross and Holstein Frisian

\begin{tabular}{|c|c|c|c|c|c|c|}
\hline Breeds & Holstein Frisian & Local & Cross & Total & Chi sq. & P-value \\
\hline Genotype & No. & No. & No. $\%$ & No. $\%$ & & \\
\hline AA & $16 \quad(19.51)$ & \begin{tabular}{|ll}
40 & $(48.78)$ \\
\end{tabular} & $26 \quad(31.71)$ & $\begin{array}{ll}82 & (100) \\
\end{array}$ & $9.516 * *$ & 0.0001 \\
\hline $\mathrm{AB}$ & (12.12) & \begin{tabular}{|ll}
20 & $(60.60)$ \\
\end{tabular} & $\begin{array}{ll}9 & (27.27) \\
\end{array}$ & \begin{tabular}{|ll}
33 & $(100)$ \\
\end{tabular} & $12.847 * *$ & 0.0001 \\
\hline Chis quire & $4.295 *$ & $4.562 *$ & $1.063 \mathrm{NS}$ & --------- & -------- & --:-- \\
\hline P-Value & 0.049 & 0.044 & 0.351 & --------- & |--------- & ------ \\
\hline
\end{tabular}

These findings were similar to those previously reported for Holstein Frisian cows [11], Iranian native, Holstein and Brown Swiss cows [12], Sahiwal and Frieswal cattle [13] as well as Holstein primiparous cows [14]. [15], reported that the most frequent homozygotes genotypes was BB, throughout their studying on Chinese indigenous cattle, and this is may be due to the nature of their race or breeds cattle population.

\section{LEP Genotypes and Body Weight (B.W):}

The relationship between LEP genotypes and body weight (B.W) were estimated, as showed in table 5. Our findings indicated that there were significant differences between local, cross and Holstein Frisian cows in all genotypes (AA and $\mathrm{AB}$ ) with $\mathrm{P}$-value 0.0019,0.0027 respectively, $(\mathrm{P}>0.01)$. 
*Institute of Genetic Engineering and Biotechnology/ University of Baghdad/Iraq

Table5: Relationship Between Genotypes of LEP Gene and Body Weight (B.W) In Three Breeds Cows.

\begin{tabular}{|c|l|l|l|l|}
\hline \multirow{2}{*}{ Genotype } & \multicolumn{2}{|c|}{ Mean \pm SE $(\mathrm{kg})$} & \multirow{2}{*}{ P-value } \\
\cline { 2 - 5 } & Cross & Local & Holstein Friesian & \\
\hline AA & $\mathbf{1 8 3 . 2} \pm \mathbf{3 . 1 0}$ & $\mathbf{1 5 2 . 0} \pm \mathbf{3 . 3 8}$ & $\mathbf{3 4 6 . 8} \pm \mathbf{2 4 . 2 5}$ & $\mathbf{0 . 0 0 1 9} * *$ \\
\hline AB & $\mathbf{1 8 3 . 8} \pm \mathbf{9 . 1 9}$ & $\mathbf{1 5 4 . 2} \pm \mathbf{3 . 6 3}$ & $\mathbf{3 8 7 . 5} \pm \mathbf{3 1 . 4 5}$ & $\mathbf{0 . 0 0 2 7} * *$ \\
\hline T-Test value & $\mathbf{1 5 . 2 1 3 ~ N S}$ & $\mathbf{1 0 . 8 8 4} \mathbf{~ N S}$ & $\mathbf{1 0 8 . 2 9} \mathbf{N S}$ & --- \\
\hline P- value & $\mathbf{0 . 9 3 4}$ & $\mathbf{0 . 7 4 8}$ & $\mathbf{0 . 4 4 0}$ & $\begin{array}{l}* * \\
(\mathbf{P}<\mathbf{0 . 0 1})-\end{array}$ \\
\hline
\end{tabular}

When the comparison between these genotypes within group was applied, there were no significant differences in LEP genotypes in local cows, cross and Holstein Frisian with P- value $(0.748,0.934,0.440)$ respectively, and $(\mathrm{P}<0.05)$.Similar results observed by [16] and [17]. Throughout their studying on beef cattle. In another study in China, indicate the association of LEP gene polymorphism with body weight evaluated to find out that the allele B might be associated with better growth traits. Cows with BB had remarkable growth [15]. Further, in our study, the associated of this candidate gene with growth traits was tested. The result of this study indicate that the LEP gene was not significant associated with body weight, suggests no feasibility as a molecular breeding marker and any significance found among these different breeds could be as a reflection of other genes involved in an encoding hormones, growth factors as well as regulatory protein .

\section{References}

[1] Friedman, J. (2014). Leptin at 20. J. Endocrinol., 223: T1-T8.

[2] Liefers, S.C.; Veerkamp, R.F.; Chilliard, Y. and Van . Der. Lende , T. (2005). Genetics and physiology of leptin in periparturient dairy cows. Domes. Anim. Endocrinol., (29):227-238.

[3] Moravcikova, N.; Trakovicka , A .; Hazuchova, E.; Bujko, J . and Kasarad, R .(2013). Associations between polymorphisms in the leptin gene and milk production traits in Pinzgau and Slovak Spotted cattle. Agris. category., 3( 259 ): 263.

[4] Liefers, S.C. and Tepas , M. F.W. (2002). Association between Leptin gene polymorphisms and production, live weight, energy balance, feed intake and fertility in Holstien heifers .J. Dairy. Sci., (85): 1633-1638.

[5] 5. Madeja, Z.; Adamowicz, T.; Chmurzynska, A.; Jankowski,T.; Melonek J. and Switonski , M . (2004). Short communication: effect of leptin gene polymorphisms on breeding value for milk production traits. J. Dairy. Sci., (87):3925-7.

[6] Javanmard, A.; Khaledi, K.; Asadzadeh, N. and Solimanifarjam, A.R. (2010). Detection of polymorphisms in the bovine leptin (LEP) gene: association of a single nucleotide polymorphism with breeding value of milk traits in Iranian Holstein cattle. J. Mol. Genet., (2): 10-14.

[7] Almeida, S.E.M.; Almeida, E.A.; Moraes , J.C.F and Weimer, T. (2003). Molecular marker in the LEP gene and reproductive performance of beef cattle. J.Anim.Breed.Geneti., 120(2): 106-113.

[8] Nkrumah, J. D.; Li, C.; Yu , J.; Hansen, C.; Keisler, D. H. and Moore, S. S.(2005). Polymorphisms in the bovine leptin promoter associated with serum leptin concentration, growth, feed intake, feeding behavior, and measures of carcass merit. J. Anim. Sci., (83):20-28.

[9] Giblin, L.; Butler, S.T.; Kearney, B.M.; Waters, S.M.; Callanan, M.J. and Berry, D.P. (2010). Association of bovine leptin polymorfphism with energy storage traits in progeny tested Holstein- Fresian dairy cattle sires. B.M.C. Genetics., (11): 73.

[10] Jecminkova, K.; Kyselova, J.; Said. Ahmed, A.; Zavadilov, L.; Matlova, V. and Majzlik , I.(2016). Leptin Promoter Region Genotype Frequencies and Its Variability in the Czech Fleckvieh Cattle. Sci agricult. Bohemica., 47 (2): 54-59.

[11] Sadeghi, M.; Babak, M.M.S.; Rahimi, G. and Javaremi, A.N. (2008). Effect of leptin gene polymorphism on the breeding value of milk production traits in Iranian Holstein. Animal., 2: 999-1002.

[12] Nassiry, M. R.; Shahroudi, F. E.; Moussavi, A. H.; Sadeghi, B. and Javadmanesh, A. (2008). The diversity of leptin gene in İranian native, Holstein and Brown Swiss cattle. S. Afr. J. Anim. Sci., 7(15): 2685-2687.

[13] Singh, U.; Kumar, S.; Deb, R.; Mann, S. and Sharma, A. (2013). Genotypic profiling of coding region of leptin gene and their association studies on reproductive and milk production traits in Sahiwal and Frieswal cattle of India. . S. Afr. J. Anim. Sci. 12 (42): 6140-6146, 16.

[14] Tomka, J.; Vasickova, K.; Oravcova, M.; Bauer, M.; Huba, J.; Vasicek, D. et al., .(2016). Effects of polymorphisms in DGAT1 and LEP genes on milk traits in Holstein primiparous cows, Mljekarstvo. 66 (2): 122-128.

[15] Yang, D.; Chen, H.; Wang, X.; Tian, Z.; Tang, L; Zhang, Z. and Zhang, L. (2007). Association of polymorphisms of leptin gene with body weight and body sizes indexes in Chinese indigenous cattle. J. Genet. Genomics., (34) :400-5.

[16] Ali Asghar, A.; Nassiry, M.R.; Farajollahi, H.; Mahdavi, M.; Abbasi H. and Javadmanesh, A. (2010). Polymorphism in Exon 3 of Leptin Gene in Iranian Native Cattle Breeds. J. Appl. Anim. Res. 37: 159-162.

[17] Woronuk, G. N. F. L.; Marquess, S. T.; James, J.; Palmer, T.; Berryere, H. and Deobald, S. (2011). Association of leptin genotypes with beef cattle characteristics . Anim. Geneti., (10) 1111:1365-2052- 02320. 